\title{
ASSESSING THE TRANSLATION OF PERSON REFERENCE FORMS IN A LITERARY TEXT: A CASE OF HARRY POTTER'S JOURNEY FROM ENGLISH TO VIETNAMESE
}

\author{
Trieu Thu Hang* \\ VNU University of Languages and International Studies, \\ Pham Van Dong, Cau Giay, Hanoi, Vietnam \\ Received 9 August 2019 \\ Revised 6 May 2019; Accepted 25 July 2019
}

\begin{abstract}
The study aims to assess the Vietnamese translation of English person reference forms, particularly "I - you" dyads in a literary text. To fulfill the purpose, House's functional-pragmatic model (House, 2015), extended with Attitudinal resources of Appraisal theory (Martin \& White, 2005), is adopted as the analytical framework for assessment. The data include 75 "I - you" dyads collected from "Harry Potter and the Philosopher's Stone" (2014) and its Vietnamese translation "Harry Potter và Hòn đá phù thuy" (2016). The research findings show the translator's attempt in selecting equivalents among the remarkably diverse system of person reference in Vietnamese to produce a functionally adequate translation in accordance with situational and cultural contexts of the target language. Grounded on research findings, target language-oriented strategy for English-Vietnamese translation of "I - you" dyads is proposed. Furthermore, the study has proved effective in extending House's model (2015) with Attitudinal resources of Appraisal theory in order to explore the attitudes of the source text writer embedded in the original, serving the benefits of translation assessment in practice.
\end{abstract}

Keywords: person reference forms, "I - you" dyads, translation quality assessment, literary translation

\section{Rationale and research aim}

A strain in translating an English literary text into Vietnamese is that Vietnamese contains remarkably diverse forms for the sole "I - you" dyad. Unarguably, it is challenging to properly render the universal "you" of English to specific forms, in which the target language (hereafter TL) not only conveys the interpersonal relations between the characters but also contributes to the portrayal of the characters' traits. Although considerable discussions have been initiated about person reference forms in English and Vietnamese, there has been a relative scarcity of studies with a view to assessing the translation quality of

\footnotetext{
* Tel.: 84-944811991

Email: trieuthuhang91@gmail.com
}

person reference forms. Therefore, this paper aims to assess the Vietnamese translation of person reference forms, particularly the "I you" dyads in a literary text.

\section{Theoretical background}

\subsection{Person reference forms}

It is common to see the terms "addressing forms, forms of address, addressing terms, terms of address" in prior research. Forms of address are words and phrases used for addressing (Braun, 1988; Yule, 2006).

Nonetheless, for the purpose of examining the functions of "I - you" dyads in contexts and their translation into Vietnamese, the term "person reference forms" (Lương Văn Hy, 1990) is employed in this study as a general heading instead of addressing forms, 
forms of address, addressing terms, or terms of address. Different from most of the IndoEuropean languages including English which count on second-person pronominal variations or vocatives to express various degrees of solidarity and power difference (Brown \& Gilman, 1960), the Vietnamese language has a multitude of terms not only for addressing people but also for self- and third-party reference. For this reason, the term "person reference forms" is employed in this study.

It is acknowledged that person reference forms cover broad categories, including occupation terms (e.g., Professor, Doctor); title terms (e.g., Mr., Ms.); honorifics (e.g., Sir, Madam); terms of intimacy (e.g., dear, love). For in-depth analysis, the present study focuses on assessing the Vietnamese translation of "I - you" dyads in the "Harry Potter and the Philosopher's Stone" (hereafter HPPS). The Harry Potter novel is composed of numerous dialogues between characters; thus, the "I - you" dyad plays a crucial role in revealing elaborate relationships as well as attitudes among characters in the narrative.

2.2 House's functional-pragmatic model for assessing person reference forms

First, a sketch of House's model is introduced to pave the way for the reasons of choosing this model. House (2015) highlights that translation is the preservation of meaning across two different languages and cultures. The two terms "context of situation" and "context of culture" are made clear in relation to House's model (2015). Context of situation refers to the environment, time and place in which the word, phrase, sentence or discourse occurs and the relationship between the participants. Context of culture refers to culture, customs, and background in language communities in which the speakers participate. More specifically, House's model (2015) is operationalized as follows:

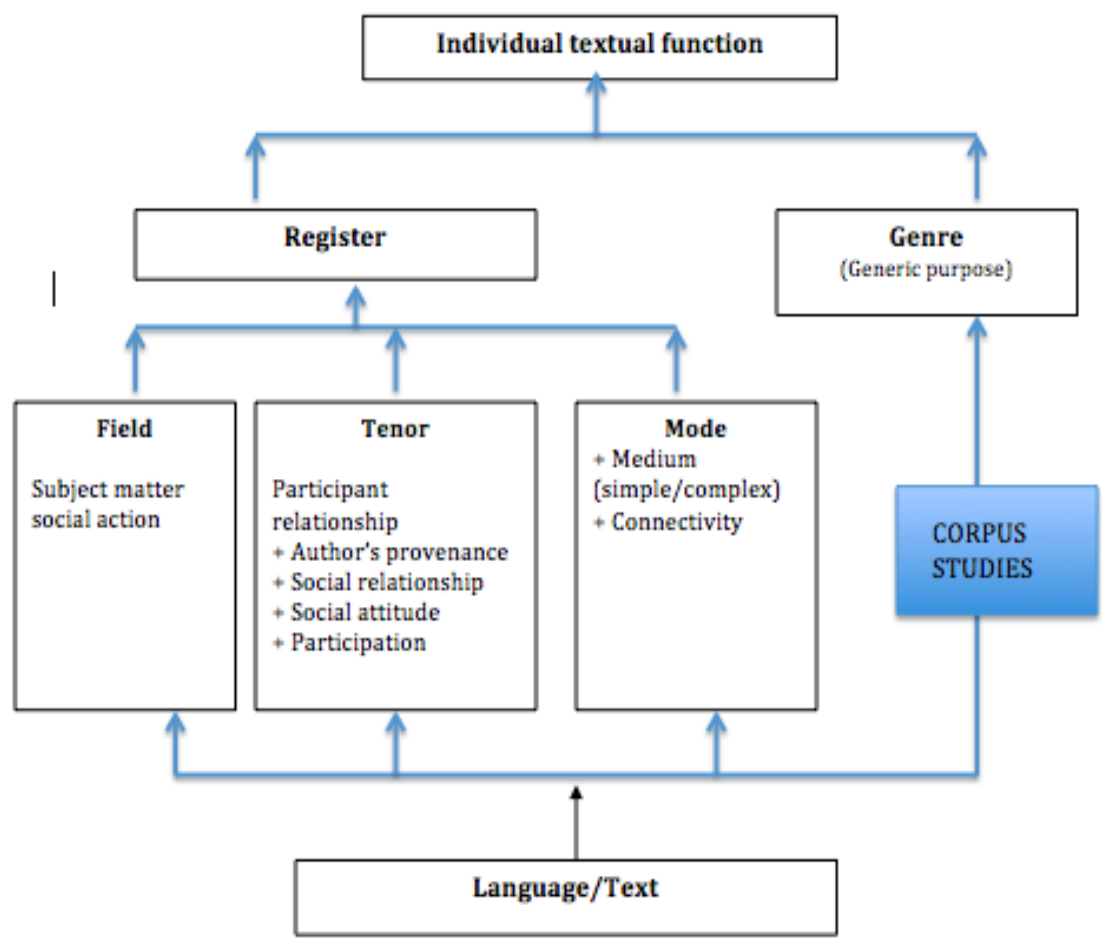

Diagram 1. House's model (2015, p.127) 
It can be seen from Diagram 1 that the operation of House's model (2015) starts from the notion of "text". The analysis of text in context of situation is realized through register analysis of Field, Tenor, and Mode. Within Register, Field refers to the ongoing activity. Tenor refers to the relationship between participants in terms of social power, social distance, social attitude, including the text producer's temporal, geographical, social provenance and his/ her viewpoint. Mode captures Medium, the channel of communication being used (writtenness or spokenness). Besides, House (2015, p. 64) indicates that "genre enables one to refer any single textual exemplar to the class of texts with which it shares a common purpose". The genre of a text is partly determined by the culture in which the text is used since different cultures achieve their purposes through language in different ways.

In House's model (2015), she adopts Halliday's terms (1973) ideational and interpersonal functions of language as two sub-components of a text's function. Ideational function serves to represent situations, events in the world and entities, actions and processes involved. Interpersonal function (Tenor) refers to how we use language to communicate; it allows us to encode meanings of attitudes, interaction and relationships. The purpose of the model is also to achieve functional equivalent between the ST and TT.

House's model is adopted as the analytical frame in this study for three main reasons. Firstly, this model has been proved to be applicable to assess the translation quality of numerous text types including scientific texts, tourist information booklets, fictional and non-fictional texts. In House (1977, 1997), this model was put to an empirical test with a corpus of eight authentic English and German textual pairs to pilot and prove its applicability towards the aforementioned text types. Secondly, House's model is "a particularly good example of how the consideration of macro- and micro-level phenomena can be integrated, rather than separated and opposed to each other, in analysis" (Steiner, 1998, p. 17). In House's model, the source text (hereafter ST) and target text (hereafter TT) are judged on both "micro-level" (lexico-grammatical features) and macro-level (register and genre). Macro-level categories such as genre and register are not neglected but serve as an important function in the generation and the interpretation of results. Thirdly, House demonstrates that her linguistic approach to translation assessment includes not only textual, situational but also cultural aspects. Since the research purpose is to assess English-Vietnamese translation of person reference forms in a literary text; therefore, both situational and cultural contexts play a crucial role in identifying the appropriate equivalents among the Vietnamese system of person reference.

In this study, Attitudinal resources of Appraisal theory (2005) is integrated into House's model for the following reasons. As a reminder, the notion of Tenor in House's model refers to the way in which linguistic choices are affected by not only the subject of communication but also the social relationship and social attitude of participants in which the communication is taking place.

Linking with Appraisal theory (Martin \& White, 2005), it should be noted that appraisal [... construes] interpersonal meaning (Martin \& White, 2005, p. 34). Appraisal theory is a sub-system of systemic functional linguistic for exploring, describing, and explaining the way language is used to evaluate, adopt stance, and construct interpersonal 
positioning and relationships (White \& Eldon, 2012). Therefore, Attitudinal resources of Appraisal theory are relevant for exploring viewpoint, attitude, feelings and emotions of the ST author within the Tenor variable of House's model. Within Appraisal theory, Attitude construes feelings, emotions and values, which could be classified into three categories:

Affect refers to language resources for construing emotional reactions, including positive or negative feelings. This domain is investigated via three main variables, namely un/happiness, in/security, dis/satisfaction.

Judgment refers to language resources for construing assessing behavior according to normative principles. Judgment is divided into social esteem and social sanction. According to Martin (2000, p. 156), Judgments of esteem have to do with normality (how unusual someone is), capacity (how capable someone is) and tenacity (how resolute someone is). Judgments of sanction have to do with veracity (how truthful someone is) and propriety (how ethical someone is).

Appreciation refers to language resources for construing the values of things (evaluation of natural phenomenon). Likewise, Appreciation has a positive and negative dimension, which includes reaction, composition and valuation (Martin, 2000 , p. 160). Reaction has to do with the emotional impact that the text/ process has on us. Composition has to do with our perceptions of proportionality and detail in a text/ process. Valuation has to do with our assessment of the social significance of the text/ process.

In short, Affect, Judgment and Appreciation are three indispensable parts to constitute Attitude subsystem as an effective means to investigate people feelings and positioning.

\section{Methodology}

This study serves as a descriptive and evaluative study. In this study, the literary text entitled "Harry Potter and the Philosopher's Stone" and its Vietnamese translation are selected. Both Harry Potter saga and HPPS have been translated into nearly 80 languages and gained notable literary prizes across the globe since 1997, which merits the research attention. The data include 75 dyads of "I you" taken from the ST "HPPS" (2014) by J. K. Rowling, and its target Vietnamese text - "Harry Potter và Hòn đá phù thuỷ" (2016) published by Trẻ Publishing House, translated by Lý Lan.

\section{Findings and discussion}

\subsection{Findings of English-Vietnamese} assessment of " $I$ - you" dyad

There are three major findings from the analysis of "I - you" dyads and their Vietnamese translation based on the analytical framework. Firstly, the Vietnamese translations of the "I-you" dyad are functionally equivalent to the ST in accordance with the situational and cultural contexts. The sole "I - you" dyad has been translated into more than 50 variants in Vietnamese in diverse situational contexts. Secondly, "I - you" dyad is not only translated into Vietnamese personal pronouns but also kinship terms. A variety of kinship nouns are used in translating "I - you" dyads from English to Vietnamese, such as "con - thầy; con - cô; ta - con; bác - các cháu; anh - em; em - anh". Thirdly, TL - oriented translation strategy is adopted in dealing with "I - you" dyads. Via such a strategy, the translator "anchors a reference firmly" in Vietnamese culture. 


\section{Excerpt 1: Context (Draco Malfoy - Ron, Harry)} ST
a.. He was looking at the other boys. Both of them were thickset
and looked extremely mean. Standing on either side of the pale boy, they looked like bodyguards.

"Oh, this is Crabbe and this is Goyle," said the pale boy carelessly, noticing where Harry was looking. "And my name's Malfoy, Draco Malfoy."

Ron gave a slight cough, which might have been hiding a snigger. Draco Malfoy looked at him.

"Think my name's funny, do you? No need to ask who you are. My father told me all the Weasleys have red hair, freckles, and more children than they can afford."

He turned back to Harry. "You'll soon find out some wizarding families are much better than others, Potter. You don't want to go making friends with the wrong sort. I can help you there."

He held out his hand to shake Harry's, but Harry didn 't take it.

"I think I can tell who the wrong sort are for myself, thanks," he said coolly.

Draco Malfoy didn't go red, but a pink tinge appeared in his pale cheeks. "I'd be careful if I were you, Potter," he said slowly. "Unless you're a bit politer you'll go the same way as your parents. They didn t know Weasleys and that Hagrid, and it'll rub off on you." ...

... Harry nói và nhìn hai đứa đi cùng. Cả hai trông chắc nịch và hung tơn. Tui nó đúng hai bên thằng bé nhợt nhạt trông nhu là vẹ sĩ. Thấy Harry nhìn hai đưa kia, thằng bé nhơt nhat hờ hũng giới thiệu: À, đây là Crabbe, còn đây là Goyle. Tao là Malfoy, Draco Malfoy.

Ron ho khẽ mấy tiếng, chắc là để ém tiếng cuời khẩy. Draco Malfoy ngó Ron: Bộ thấy tên tao buồn cườ lắm hả? Tên mày tao chua thèm hỏi nha! Ba tao đã nói cho tao biết hết về tui tóc đỏ Weasley nhà mày rồi, mặt đầy tàn nhang, con thì đông đến nổi nuôi không xuể chú gì! Nó quay lại Harry: Potter à, rồi mày sẽ thấy là có nhũng gia đình phù thủy sang hơn. Mày đùng vội kết bạn với đám tâm thương. Chuyện đó tao giúp mày được. Nó gió tay để bắt tay Harry, nhung Harry không thèm nắm lấy. Harry chì lạnh nhạt nói: Cám ơn. Tao nghĩ tu tao cũng biết được đứa nào tầm thưòng, đứa nào không rồi! Nghe đến đó. Draco Malfoy không đến nỗi đơ mặt, nhung hai gò má nó cũng hơ đồi màu. Nó chậm rã̃i nói: Nếu tao là mày, Potter, tao sẽ cẩn thân hơn môt chút. Mà̀y rồi sẽ đi vào vết xe đổ của ba má mày nếu không biết lễ phép hơn. Tại ba má mày hồi đó cũng không biết diều gì là tốt cho họ. Mày mà cú giao du với đám gié rách nhu bọn Weasley và lão Hagrid ây thi có ngày cũng tiêu ma. ...

Chương 6 (Harry Potter và Hòn đá phù thuỷ)

\section{ST ANALYSIS \\ FIELD}

This excerpt is about the first meeting among three characters, Harry, Ron, and Draco Malfoy at the wizarding school. A high density of adjectives is employed to describe the traits of characters (e.g., pale, thickset, mean, better, wrong). There is a predominance of relational processes to depict the characters. (e.g., both of them were thickset and extremely mean; they looked like bodyguards; this is Crabbe;

this is Goyle; my name's Malfoy; all the Weasleys have red hair; some families are much better than others). This distribution is to describe the attributes of the characters.

\section{TENOR}

Author's temporal, social and geographical provenance: unmarked English is used.

Author's stance: As justified, Attitudinal resources of Appraisal theory are adopted in order to uncover the author's attitude.

Table 1. Author's attitudes towards the relationship between characters

\begin{tabular}{|c|c|c|c|c|c|}
\hline \multirow[t]{2}{*}{ Appraising items } & \multirow[t]{2}{*}{ Appraiser } & \multicolumn{3}{|c|}{ Attitude } & \multirow[t]{2}{*}{ Appraised } \\
\hline & & Affect & Judgment & Appreciation & \\
\hline pale & Harry & & & $\begin{array}{c}- \\
\text { reaction }\end{array}$ & Draco \\
\hline thickset & Harry & & & $\begin{array}{c}\text { - } \\
\text { reaction }\end{array}$ & Draco's friend \\
\hline (extremely) mean & Harry & & $\begin{array}{c}- \\
\text { propriety }\end{array}$ & & Draco's friend \\
\hline carelessly & Harry & & $\begin{array}{c}- \\
\text { tenacity }\end{array}$ & & Draco \\
\hline much better (than others) & Draco & & & $\begin{array}{c}+ \\
\text { valuation }\end{array}$ & himself \\
\hline wrong (sort) & Draco & & & $\begin{array}{c}\text { - } \\
\text { reaction }\end{array}$ & Ron \\
\hline bravely & author & & $\begin{array}{c}+ \\
\text { tenacity }\end{array}$ & & Harry \\
\hline
\end{tabular}


The use of lexical items denoting negative affect reveals disapproving attitudes among the characters. Draco adopts a negative attitude towards Ron via the use of lexical means such as “wrong sort, riff-raff". Harry and Ron also take a negative attitude towards Draco via lexical means such as "look extremely mean, carelessly, snigger, coolly".

\section{Social role relationship}

+ Relationship between the author and the readers: symmetrical

+ Relationship among characters themselves: symmetrical among Harry, Ron, and Draco. They are male students at the same age attending the magical school.

Social attitude: marked by informality. Spoken language is employed in the extract.

The contractions in spoken language are employed (e.g., Think my name's funny, do you?; You'll soon find out some wizarding families are much better than others; I'd be careful if I were you; Unless you're a bit politer, you'll go the same way as your parents). Phrasal verbs are employed (e.g., hang around, rub off on).
The use of full name "Draco Malfoy" and last name "Potter" shows the distance in terms of the relationship between Draco Malfoy and Harry Potter (e.g., My name is Malfoy, Draco Malfoy; You'll soon find out some wizarding families are much better than others, Potter; I' $d$ be careful if I were you, Potter).

Participation: complex with both monologue and dialogue.

MODE: written to be read

GENRE: a fictional text to entertain and inform the readers

STATEMENT OF FUNCTION: the ideational function is manifested by the lexical means of adjectives to describe the traits of the characters. There is a predominance of relational processes to introduce characters. The negative attitude and distance among characters are revealed via the Attitudinal resources analysis. The ST analysis also shows the informality between these students.

\section{COMPARISON BETWEEN ST AND TT}

Table 2. ST-TT comparison of Excerpt 1

\begin{tabular}{|c|c|c|c|c|c|}
\hline \multicolumn{3}{|c|}{ Source Text profile } & \multicolumn{3}{|c|}{ Target Text profile } \\
\hline Field & Subject matter & boarding school life & Field & Subject matter & boarding school life \\
\hline \multirow[t]{5}{*}{ Tenor } & $\begin{array}{l}\text { Author's } \\
\text { provenance }\end{array}$ & a British novelist & Tenor & $\begin{array}{l}\text { Translator's } \\
\text { provenance }\end{array}$ & $\begin{array}{c}\text { a Vietnamese } \\
\text { novelist, a translator }\end{array}$ \\
\hline & $\begin{array}{l}\text { Author's } \\
\text { Stance }\end{array}$ & $\begin{array}{c}\text { disapproving } \\
\text { attitudes, hostile } \\
\text { relationship } \\
\text { among characters } \\
\text { in informal } \\
\text { situations }\end{array}$ & & $\begin{array}{c}\text { Translator's } \\
\text { Stance }\end{array}$ & $\begin{array}{l}\text { disapproving } \\
\text { attitudes, hostile } \\
\text { relationship among } \\
\text { characters in } \\
\text { informal situations }\end{array}$ \\
\hline & $\begin{array}{l}\text { Social role } \\
\text { relationship }\end{array}$ & symmetrical & & $\begin{array}{l}\text { Social role } \\
\text { relationship }\end{array}$ & symmetrical \\
\hline & Social attitude & informal & & Social attitude & informal \\
\hline & Participation & complex & & Participation & complex \\
\hline Mode & \multicolumn{2}{|c|}{ written to be read } & Mode & \multicolumn{2}{|c|}{ written to be read } \\
\hline Genre & \multicolumn{2}{|c|}{$\begin{array}{l}\text { a fictional text to entertain and } \\
\text { inform the readers }\end{array}$} & Genre & \multicolumn{2}{|c|}{$\begin{array}{l}\text { a fictional text to entertain and inform } \\
\text { the readers }\end{array}$} \\
\hline
\end{tabular}




\section{STATEMENT OF QUALITY}

In this excerpt, "tao - mày" in the TT is functionally equivalent to "I - you" dyad in the ST. "Tao - mày" in Vietnamese, which denotes the Horizontal relationship Type I (Nguyễn Quang, 2018), is employed to express anger and hostility between two students of the same social status in an informal situation.

Firstly, "tao - mày" conveys the ST author's attitudes. The negative attitude is reflected in the TT via the use of equivalent appraising items with negative connotations in Vietnamese.

Table 3. Author's and translator's attitudes towards the relationship between characters

\begin{tabular}{|c|c|c|c|c|c|c|}
\hline \multirow{2}{*}{$\begin{array}{l}\text { Appraising items } \\
\text { in English }\end{array}$} & \multirow{2}{*}{$\begin{array}{c}\text { Equivalent } \\
\text { appraising items in } \\
\text { Vietnamese }\end{array}$} & \multirow[t]{2}{*}{ Appraiser } & \multicolumn{3}{|c|}{ Attitude in Appraisal theory } & \multirow[t]{2}{*}{ Appraised } \\
\hline & & & Affect & Judgment & Appreciation & \\
\hline pale & nhợt nhạt & Harry & & & $\begin{array}{c}\text { - } \\
\text { reaction }\end{array}$ & Draco \\
\hline thickset & chắc nịch & Harry & & & $\begin{array}{c}\text { - } \\
\text { reaction }\end{array}$ & Draco's friend \\
\hline (extremely) mean & hung tợn & Harry & & $\begin{array}{c}- \\
\text { propriety }\end{array}$ & & Draco's friend \\
\hline carelessly & hờ hững & Harry & & $\begin{array}{c}- \\
\text { tenacity }\end{array}$ & & Draco \\
\hline $\begin{array}{l}\text { much better (than } \\
\text { others) }\end{array}$ & sang hơn & Draco & & & $\begin{array}{c}+ \\
\text { valuation }\end{array}$ & himself \\
\hline wrong sort & đám tầm thường & Draco & & & $\begin{array}{c}- \\
\text { reaction }\end{array}$ & Ron \\
\hline bravely & can đảm & author & & $\begin{array}{c}+ \\
\text { tenacity }\end{array}$ & & Harry \\
\hline
\end{tabular}

The choice of "tao - mày" recreates the negative attitudes among characters in the TT. In line with "tao - mày", the use of Vietnamese lexical items with negative nuances such as "hờ hững, đám tầm thường, đám giẻ rách" fulfills the purposes of the ST author about the disapproving attitudes among characters. The TT also recreates the negative attitude of Harry and Ron towards Draco (e.g., look extremely mean - hung tợn, carelessly - hờ hững, snigger - cười khẩy, coolly - lạnh nhạt) and Draco's negative attitude towards Ron and Harry (e.g., wrong sort: đám tầm thường, riff - raff: đám giẻ rách).

Secondly, the selection of "tao - mày" contributes to the overall informal atmosphere of the situation. Such informality is recreated in the TT via the use of colloquialisms (e.g., hang around - giao du, riff raff - đám giẻ rách, rub off on - có ngày cũng tiêu ma, go the same way - đi vào vết xe đổ). Thus, "tao - mày" gives rise to the entire informality of the situation given in the above excerpt.

Thirdly, the choice of "tao - mày" gives a hand in reflecting the distance in terms of the relationship between Draco Malfoy and Harry Potter. In Vietnamese, the $1^{\text {st }}$ person singular pronoun "tao" (I) and its reciprocals "mày" (you) in the $2^{\text {nd }}$ person are used primarily among close friends of the same age to express intimacy. By contrast, "tao" and "mày" also imply strong disrespect and arrogance. In this excerpt, the choice of "tao" and "mày" functions as a vehicle to show distance and hostile relationship between Draco on one side and Harry and Ron on the other side in an informal situation. Thus, "tao - mày" is functionally equivalent "I - you" dyad in the ST in accordance with the examined situational and cultural contexts. 
Excerpt 2: Context (Professor McGonagall - students)

\begin{abstract}
ST
“Welcome to Hogwarts, " said Professor McGonagall.

"The start-of-term banquet will begin shortly, but before you take your seats in the Great Hall, you will be sorted into your houses. The Sorting is a very important ceremony because, while you are here, your house will be something like your family within Hogwarts. You will have classes with the rest of your house, sleep in your house dormitory, and spend free time in your house common room.

"The four houses are called Gryffindor, Hufflepuff, Ravenclaw, and Slytherin. Each house has its own noble history and each has produced outstanding witches and wizards. While you are at Hogwarts, your triumphs will earn your house points, while any rule breaking will lose house points. At the end of the year, the house with the most points is awarded the house cup, a great honor. I hope each of you will be a credit to whichever house becomes yours.

"The Sorting Ceremony will take place in a few minutes in front of the rest of the school. I suggest you all smarten yourselves up as much as you can while you are waiting."
\end{abstract}

Chapter 7

(Harry Potter and the Philosopher's Stone)

\section{ST ANALYSIS}

\section{FIELD}

The excerpt is about the commencement of the Sorting Ceremony. This Ceremony serves as a special ceremony at the beginning of the school year at the wizarding school. A number of lexical items is employed to signal the ceremony opening (e.g. welcome to; sorted into;

TT

Giáo su McGonagall cất lời: Chào mùng các con đến Hogwarts. Tiệc khai giảng sắp bắt đầu, nhung truớc khi nhận chố ngồi trong Đại Sảnh đưòng, các con sẽ được phân loại để xếp vào các ký túc xá. Phân loại là một lễ rất quan trong, bởi vì trong thời gian các con học ở đây, ký túc xá của con cũng giống nhu gia đình của con trong truờng Hogwarts. Các con sẽ cùng học, cùng ngủ, cùng choi ... với các bạn chung một ký túc xá.

Có bốn ký túc xá, ở đây gọi là "nhà", nhà Gryffindor, nhà Hufflepuff, nhà Ravenclaw và nhà Slytherin. Mỗi "nhà" đều có một lịch sủ cao quý riêng và "nhà" nào cũng tùng tao nên nhũ̃ng nam phù thủy và nũ phù thủy xuất sắc. Trong thời gian các con họ ở Hogwarts thì thành tích các con đạt được sẽ đuợc cộng vào điểm chung cho "nhà" mình ơ: Cuối năm, "nhà" nào có được nhiều điểm nhất sẽ đuợc nhận Cúp Nhà - một vinh dụ cao cả. Ta hy vọng mỗi nguò̀i trong các con là một thành viên xúng đáng với "nhà" mình sống, cho dù các con được chọn vào "nhà" nào đi nữa.

Lễ phân loại sẽ diễn ra trong vài phút tới, truớc mặt toàn thế giáo viên và học sinh trong truờng. Ta đề nghị các con sủa soạn cho tề chỉnh trong khi chờ đợi làm lễ.

Table 4. Author's attitudes (Professor McGonagall - Sorting Ceremony)

\begin{tabular}{|c|c|c|c|c|c|}
\hline \multirow[t]{2}{*}{ Appraising items } & \multirow[t]{2}{*}{ Appraiser } & \multicolumn{3}{|c|}{ Attitude } & \multirow[t]{2}{*}{ Appraised } \\
\hline & & Affect & Judgment & Appreciation & \\
\hline Important & $\begin{array}{c}\text { Professor } \\
\text { McGonagall }\end{array}$ & & & $\begin{array}{c}+ \\
\text { valuation }\end{array}$ & Sorting Ceremony \\
\hline $\begin{array}{l}\text { Notable } \\
\text { (history) }\end{array}$ & $\begin{array}{c}\text { Professor } \\
\text { McGonagall }\end{array}$ & & & $\begin{array}{c}+ \\
\text { valuation }\end{array}$ & Each house \\
\hline Outstanding & $\begin{array}{c}\text { Professor } \\
\text { McGonagall }\end{array}$ & & $\begin{array}{c}+ \\
\text { capacity }\end{array}$ & & $\begin{array}{l}\text { Witches and wizards in each } \\
\text { house }\end{array}$ \\
\hline Great (honor) & $\begin{array}{c}\text { Professor } \\
\text { McGonagall }\end{array}$ & & & $\begin{array}{c}+ \\
\text { valuation }\end{array}$ & Receiving house's cup \\
\hline
\end{tabular}


The analysis reveals Professor McGonagall's positive attitude towards the Sorting Ceremony.

Social role relationship:

+ Relationship between the author and readers: symmetrical

+ Relationship between the author and characters: The author implies respect to Professor McGonagall, the deputy head of the wizarding school.

+ Relationship among the characters: hierarchical between Professor McGonagall and first-year students.

Social attitude: formal. Passive structures (e.g., you will be sorted into your houses; the house with the most points is awarded the house cup) are used. There are structures involving subjunctive mood (e.g., I suggest you all smarten yourselves) to denote formality. There is also the use of noun phrases to express formality (e.g., the Great Hall; a very important ceremony; a notable history, a great honor; outstanding witches and wizards).

Participation: simple (monologue)

MODE: written to be read

GENRE: a fictional text to entertain and inform the readers

\section{STATEMENT OF ST FUNCTION:} The ideational function is marked by a predominance of relational processes in which the Professor stresses the essence of the Sorting Ceremony. The interpersonal function is marked by the author's attitude, social role relationship, and social attitudes. There is a hierarchical relationship between the Professor and her students. The ST analysis also reveals the formality of the Sorting Ceremony.

COMPARISON BETWEEN ST AND TT

Table 5. ST-TT comparison of Excerpt 2

\begin{tabular}{|c|c|c|c|c|c|}
\hline \multicolumn{3}{|c|}{ Source Text profile } & \multicolumn{3}{|c|}{ Target Text profile } \\
\hline Field & Subject matter & boarding school life & Field & Subject matter & boarding school life \\
\hline \multirow[t]{5}{*}{ Tenor } & $\begin{array}{l}\text { Author's } \\
\text { provenance }\end{array}$ & a British novelist & \multirow[t]{5}{*}{ Tenor } & $\begin{array}{l}\text { Translator's } \\
\text { provenance }\end{array}$ & $\begin{array}{l}\text { a Vietnamese novelist, } \\
\text { a translator }\end{array}$ \\
\hline & $\begin{array}{l}\text { Author's } \\
\text { Stance }\end{array}$ & $\begin{array}{l}\text { Professor's positive } \\
\text { attitude towards her } \\
\text { students }\end{array}$ & & $\begin{array}{l}\text { Translator's } \\
\text { Stance }\end{array}$ & $\begin{array}{l}\text { Professor's positive } \\
\text { attitude towards her } \\
\text { students }\end{array}$ \\
\hline & $\begin{array}{l}\text { Social role } \\
\text { relationship }\end{array}$ & symmetrical & & $\begin{array}{l}\text { Social role } \\
\text { relationship }\end{array}$ & symmetrical \\
\hline & \begin{tabular}{|l|} 
Social attitude \\
\end{tabular} & informal & & \begin{tabular}{|l|} 
Social attitude \\
\end{tabular} & informal \\
\hline & Participation & simple (monologue) & & Participation & simple (monologue) \\
\hline Mode & \multicolumn{2}{|c|}{ written to be read } & Mode & \multicolumn{2}{|c|}{ written to be read } \\
\hline Genre & \multicolumn{2}{|c|}{$\begin{array}{l}\text { a fictional text to entertain and inform } \\
\text { the readers }\end{array}$} & Genre & \multicolumn{2}{|c|}{$\begin{array}{l}\text { a fictional text to entertain and inform the } \\
\text { readers }\end{array}$} \\
\hline
\end{tabular}

\section{STATEMENT OF QUALITY}

In this excerpt, "ta - các con" in the TT is functionally equivalent to "I - you" in the ST. "Ta - các con" in Vietnamese, which denotes the dynamic relationship Type II (Nguyễn Quang, 2018), is employed to address a person of lower social status to show solidarity.
Firstly, the choice of "ta - các con" expresses Professor McGonagall's positive attitude towards the Sorting Ceremony. Together with the pronouns "ta - các con", formal lexical items such as "quan trong, lịch sử cao quý, vinh dụ cao cả, nhĩng nam phù thuỷ và nũ phù thuỷ xuất sắc" help to highlight Professor's positive attitude towards the Ceremony. 
Secondly, the choice of "ta - các con" indicates the higher social status of Professor McGonagall as a deputy headmaster. In Vietnamese, "ta" is used in a variety of situations. In the plural usage, "ta" functions as first person inclusive plural "chúng ta" meaning "I/ we including you" in English, and both are regularly used in formal situations. When being used as a singular pronoun, "ta" implies the speaker's superiority over the addressee. "Ta" is also employed in literature to express intimacy in which its corresponding second person is "mình". In this examined context, "ta" is used to underline the superiority and the high social status of Professor McGonagall.

Concerning the use of kinship, in the situation given in the above excerpt, the professor's purpose is to welcome new students to the school of wizards and create a cozy atmosphere. In Vietnamese, kinship terms carry the primary meaning of denoting blood relationship. Regarding extended meaning, they are used between non-related people to express intimacy, respect, affection, and formality. Thus, the use of "ta - các con" fulfills the function of reflecting both formality and affection between the Professor and students.

In the subsequent excerpt, the translator shows a different choice in the equivalent for "I - you" dyad between a different Professor and students. Consider the following excerpt:

Excerpt 3: Context (Professor Snape - students)

\begin{tabular}{l} 
ST \\
\hline Snape finished calling the names and looked up at \\
the class. His eyes were black like Hagrid's, but \\
they had none of Hagrid's warmth. They were cold \\
and empty and made you think of dark tunnels. \\
"You are here to learn the subtle science and exact \\
art of potionmaking," he began. He spoke in barely \\
more than a whisper, but they caught every word \\
- like Professor McGonagall, Snape had y caught \\
every word - like Professor McGonagall, Snape \\
had the gift of keeping a class silent without effort. \\
"As there is little foolish wand-waving here, many of \\
you will hardly believe this is magic. I don't expect \\
you will really understand the beauty of the softly \\
simmering cauldron with its shimmering fumes, the \\
delicate power of liquids that creep through human \\
veins, bewitching the mind, ensnaring the senses... \\
I can teach you how to bottle fame, brew glory, \\
even stopper death - if you aren't as big a bunch of \\
dunderheads as I usually have to teach."
\end{tabular}

Chapter 8

(Harry Potter and the Philosopher's Stone)

\section{ST ANALYSIS}

\section{FIELD}

The extract is about a potion lesson of Professor Snape at the wizarding school. Potion functions as a major subject at this school. Lexical items related to Potion lesson are employed (e.g., subtle science, potion making, the softly simmering cauldron, shimmering fumes, liquids).

\begin{abstract}
Thầy Snape diêm danh xong thi ngước nhin cả lớp. Mắt ông cũng đẹn nhu mắt bác Hagrid, nhưng chúng không hề ấm áp nhu mắt bác Hagrid. Chúng lạnh lùng và trống rống, làm người ta liên tương đến những đường hầm tôi om. Thầy Snape bắt đầu: Chúng bây tới đây để hoc mọt bộ môn khoa học tinh tế và một nghê thuật chính xác là chế tạo độc duợc. Giọng thầy không to, thật ra chỉ to hơn tiếng thì thầm một chút, nhung bon trẻ lắng nghe không sót một lời. Thầy Snape có biệt tài nhi giáo su McGonagall là không cần phải mất công mà vẫn giũ được lóp học im lậng nhu tò̀.

Vi trong lãnh vực này không cần phải vung vẩy đũa phép nhiều cho lằm, nên thường chúng bây không tin rằng đây cũng là một loại hình pháp thuật. Ta không trông mong gì chúng bây thực sư hiếu được cái đẹp của nhũng cái vạc sủi tăm nhè nhe, toả làn huơng thoang thoảng; cũng chẳng mong gì chúng bầy hiêu được cái súc manh tinh vi của những chât lỏng lan trong mạch máu người, làm mê hoạc đầu óc người ta, làm các giác quan bi mấc bầy... Nhung ta có thể dạy cho chúng bây cách đóng chai danh vọng, chế biến vinh quang, thậm chícầm chân thần chết - nếu chúng bây không phải là một lũ đầu bò mà lâu nay ta vẫn phải dạy.
\end{abstract}

Chương 8

(Harry Potter và Hòn đá phù thuỷ)

\section{TENOR}

Author's temporal, social and geographical provenance: unmarked English is used.

Author's attitude: As justified, Attitudinal resources of Appraisal theory are adopted to explore the author's attitude. The negative attitude towards Snape is revealed via the analysis below: 
Table 6. Author's attitudes towards the relationship between characters

(Professor Snape - Students)

\begin{tabular}{|c|c|c|c|c|c|}
\hline \multirow[t]{2}{*}{ Appraising items } & \multirow[t]{2}{*}{ Appraiser } & \multicolumn{3}{|c|}{ Attitude } & \multirow[t]{2}{*}{ Appraised } \\
\hline & & Affect & Judgment & Appreciation & \\
\hline black & Harry & & & $\begin{array}{c}- \\
\text { reaction }\end{array}$ & Snape \\
\hline cold & Harry & & & $\begin{array}{c}- \\
\text { reaction }\end{array}$ & Snape \\
\hline empty & Harry & & & $\begin{array}{c}- \\
\text { reaction }\end{array}$ & Snape \\
\hline foolish & Snape & & $\begin{array}{c}- \\
\text { capacity }\end{array}$ & & students \\
\hline dunderhead & Snape & & $\begin{array}{c}- \\
\text { capacity }\end{array}$ & & students \\
\hline
\end{tabular}

Social role relationship:

+ Relationship between the author and the readers: symmetrical relationship

+ Relationship among the characters: hierarchical between Professor Snape and new students at the school.

Social attitude: there is a mixture of formality and informality. The author uses noun phrases to express the formality of a class (e.g., the subtle science, exact art of potion-making, the softly simmering cauldron, shimmering fumes, the delicate powers of liquid). Besides, informal phrases are also used (e.g., a bunch of dunderheads, foolish wand).

Participation: simple (monologue)

MODE: written to be read

GENRE: a fictional text to entertain and inform the readers

STATEMENT OF ST FUNCTION: The ideational function is expressed through the subject matter about a potion class at a wizarding school. The negative attitude of Professor Snape towards students is revealed. There is a hierarchical relationship between the Professor and his students.

\section{COMPARISON BETWEEN ST AND TT}

Table 7. ST-TT comparison of Excerpt 3

\begin{tabular}{|c|c|c|c|c|c|}
\hline \multicolumn{3}{|c|}{ Source Text profile } & \multicolumn{3}{|c|}{ Target Text profile } \\
\hline Field & Subject matter & boarding school life & Field & Subject matter & boarding school life \\
\hline \multirow[t]{5}{*}{ Tenor } & $\begin{array}{l}\text { Author's } \\
\text { provenance }\end{array}$ & a British novelist & \multirow[t]{4}{*}{ Tenor } & $\begin{array}{l}\text { Translator's } \\
\text { provenance }\end{array}$ & $\begin{array}{l}\text { a Vietnamese } \\
\text { novelist, a translator }\end{array}$ \\
\hline & $\begin{array}{l}\text { Author's } \\
\text { Stance }\end{array}$ & $\begin{array}{l}\text { Professor's } \\
\text { arrogance and his } \\
\text { negative attitudes } \\
\text { towards the students }\end{array}$ & & $\begin{array}{l}\text { Translator's } \\
\text { Stance }\end{array}$ & $\begin{array}{l}\text { Professor's } \\
\text { arrogance and his } \\
\text { negative attitudes } \\
\text { towards the students }\end{array}$ \\
\hline & $\begin{array}{l}\text { Social role } \\
\text { relationship }\end{array}$ & symmetrical & & $\begin{array}{l}\text { Social role } \\
\text { relationship }\end{array}$ & symmetrical \\
\hline & Social attitude & informal & & Social attitude & informal \\
\hline & Participation & simple (monologue) & & Participation & simple (monologue) \\
\hline Mode & \multicolumn{2}{|c|}{ written to be read } & Mode & \multicolumn{2}{|c|}{ written to be read } \\
\hline Genre & \multicolumn{2}{|c|}{$\begin{array}{l}\text { a fictional text to entertain and inform } \\
\text { the readers }\end{array}$} & Genre & \multicolumn{2}{|c|}{$\begin{array}{l}\text { a fictional text to entertain and inform the } \\
\text { readers }\end{array}$} \\
\hline
\end{tabular}




\section{STATEMENT OF QUALITY}

In this excerpt, "ta - chúng bây" in the TT is functionally equivalent to "I - you" dyad in the ST. "Ta - chúng bây" in this context is used to express the arrogance of the Professor, his disrespect, and his negative attitudes towards students.

Firstly, the choice of "ta - chúng bây" depicts Professor Snape's negative attitude towards students. In the TT, equivalent appraising items provoking negative nuances such as "lũ đầu bò" are employed to express Professor Snape's negative attitude towards students.

Secondly, "ta - chúng bây" is to express the hierarchy between Professor Snape and students. "Ta" is to express the higher social status of Professor Snape as a potion master at the wizarding school. As mentioned, "ta" can be used as either singularly or plurally to mean "I" or "we" respectively in Vietnamese. When used as a singular pronoun, "ta" underscores the speaker's superiority over the addressee. In this case, "ta" is to express Professor Snape's superiority over students. Together with "chúng bây", it also displays his arrogance and disrespect to students. In brief, "ta - chúng bây" is functionally equivalent to "I - you" in the ST in accordance with its examined context.

To put it briefly, the aforementioned analyses show the attempt of the translator in selecting equivalents amongst the complex Vietnamese system of person reference to convey the meanings of the "I - you" dyads in the ST. The meanings and implications manipulated via the use of the Vietnamese person reference forms play a valuable role in acquiring a profound understanding of the original text. The characters' attitudes and social role relationships, as well as the varying degrees of formality embedded in "I - you" dyads in the ST are conveyed through the selection of person reference forms in Vietnamese undertaken by the translator. The equivalents given in the translation are considered adequate in conveying the linguistic forms, meanings, and the pragmatic implications of the original "I - you" dyads from the functional-pragmatic perspective of House's model.

Significantly, the attempt of the translator in selecting person reference forms contributes to not only denoting the relationships between characters but also depicting the traits of the characters. We can see an interesing link between the purposeful proper names of characters (Triệu Thu Hằng, 2018) and person reference forms used by the characters. For instance, Draco Malfoy who is jealous, careless, boastful, receives the name provoking negative connotation (Draco means dragon; Mal means bad; foy means faith). Linking to his name and his traits, he uses "tao - mày" to talk to their peers from the beginning to the end of the whole story. This manner of addressing discloses his personality of arrogance, disrepect towards his peers. Another example is Professor Minerva McGonagall, who receives the mythological Greek name of Goddess of wisdom. She is described as a clever professor at school of wizards. Linking to her name and her traits, she uses "ta - các con" to address students. Her manner of addressing facilitates the reader in visualizing her personality, contributing to the success of the whole literary text. Take another case as an example - Professor Severus Snape. He is cold and strict, which links to his name "Severus Snape". For a British reader, the surname "Snape" might provoke negative connotation. It derives from

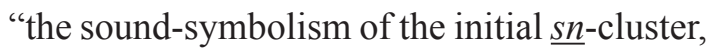
which features in words such as $\underline{s n e e r} \underline{s n i d e, ~}$ snoop, sneak, snap or even snake" (Davis, 2003, p. 79), which is closely associated with 
the "Snake" symbol of Slytherin House where this character is the head teacher. Linking to his name and his traits, he uses "ta - chúng bây" to address students. Her manner of addressing also helps the reader visualize his trait, contributing to the entire textual effect.

\subsection{Discussion of English-Vietnamese translation assessment of person reference forms}

It is inferred from the research findings that the English-Vietnamese assessment of person reference forms shows the linguistic and cultural differences between English and Vietnamese. While the number of English personal pronouns is seven (Quirk, 1973), the number of English personal pronouns is twenty (Diệp Quang Ban \& Hoàng Văn Thung, 1996; Nguyễn Thiện Giáp, 2004). In English, there merely exists a neutral dyad "I - you", which is used in communication as prefabricated units. It means that these units can be used in any context and with any person. However, the choice for "I - you" dyad is more diverse in Vietnamese.

A marked difference is that there is a tendency towards the use of kinship terms in Vietnamese. This finding is in line with Trần Ngọc Thêm (1999) in which a wealth of kinship nouns are used as addressing words in Vietnamese. There is a plenty of evidence in the case of Harry Potter novel to support this view. For instance, "I - you" is rendered into "bác cháu; ta - con; ta - các con". The Vietnamese kinship terms are more complex and extensive in terms of meaning than the English ones. Regarding primary meaning, Vietnamese kinship terms denote blood relationship. As for extended meaning, they are used between non-related people. In literary use, they imply various degree of intimacy, respect, affection or formality. The use of kinship terms depends on numerous contextual factors, including communicative purposes, interpersonal relationship between participants, and social attitude. To explain the tendency of using kinship terms, Cao Xuân Hạo (2001, p. 297) notes that Vietnamese personal pronouns "are perceived as not showing respect and cannot be used in daily life communication with people outside the family". Therefore, to show respect or politeness towards other interlocutors, the Vietnamese tend to use a number of kinship nouns as addressing words in their communication.

As a result, the use of target languageoriented translation strategy has lead to the gain of socio-cultural and pragmatic implications of Vietnamese terms of person reference. Target language-oriented translation strategy is adopted in which the translator anchors a reference firmly in the target culture. It can be seen that cultural filter is adopted by the translator. Cultural filter refers to a means of capturing sociocultural differences in expectation norms and stylistic conventions between the source and target linguistic-cultural communities (House, 1977). In my point of view, the translator is successful in breaking through the cultural barriers between English and Vietnamese to recreate a functionally adequate translation in comparison to the original. We can see the translator's attempt in selecting appropriate equivalents among the diversity of person reference forms in Vietnamese to convey the varying degrees of connotations in accordance with situational contexts.

Underlying the linguistic surface, there exists the deep layer of culture (Nguyễn Hoà, 2018). At this point, I refer to cultural values dimensions (Hofstede, 2010) in order to justify the linguistic and cultural 
differences between "I - you" dyad in English and a wealth of person reference forms in Vietnamese. The cultural value that is attached to power is labelled as Power Distance. Since Harry Potter novel is situated in both the real-life world in Great Britain and an imaginary world of wizards, I shall refer to cultural values associated with Great Britain in comparison to Vietnam. According to Hofstede (2010, p.96-97), while Great Britain is a low Power Distance country with the index of 35, Vietnam is a high Power Distance with the index of 70. High Power Distance societies are characterized by hierarchical levels. At family, parents teach their children to be obedient. Children must show respect for parents, grandparents, relatives, and the elders. At school, students show high respect for teachers. Teachers monitor all the activities in class. In the society system, the communication roles are determined by age, social status, and communicative situations. On the other hand, low Power Distance societies are characterized by the tendency towards egalitarianism. At family, parents treat their children equally. Children treat their parents, relatives, and the elders equally. At school, students treat their teachers equally, and teachers want students to be active in their own activities in class.

Since literary texts display numerous linguistic peculiarities, as well as social and cultural aspects of daily lives, we can see such cultural values reflected in the Harry Potter novel and its Vietnamese translation. In the original, the professors use "I - you" to address students, and students also use "I - you" to address their professors. This manner of addressing shows the tendency towards egalitarianism in low Power Distance societies. On the other hand, we can see various forms of "I-you" (cô - con, con cô, con - thầy; thầy - con; tao - mày, etc.) in the Vietnamese translation. Such usage also reflects the hierarchical levels in high Power Distance societies like Vietnam. Such justification helps to reinforce the strong bond between language, culture, and thought.

To further justify the bond between cultural values and linguistic usage, it is of significance to scrutinize history. Historically, English is a West Germanic language brought to Britain in the mid $5^{\text {th }}$ to $7^{\text {th }}$ centuries $\mathrm{AD}$ by Anglo-Saxon settlers. Notably, the regions of European using Germanic languages are divided into many tribes monitored by local authorities instead of any other rulers, which could be linked to low Power Distance cultural value as today (Hofstede, 2010, translated by Đinh Việt Hoà, 2015). By contrast, Vietnam is a multi-ethnic and multi-lingual country whose history dates back to 2879B.C.E. The country was first conquered by the Chinese for nearly one thousand year from 111B.C.E. to 939 C.E. During the subsequent centuries, Vietnam was conquered by the Chinese until the mid-nineteenth century. According to Nguyễn Văn Huyên (2002), intellectual activities in Vietnam reflected a blending of Confucianism. Goodman (2005, p.31) asserts, "the Vietnamese view of the world and how it worked, of family and society and the roles of its members, and of concepts of duty and virtue, all bore a heavy resemblance to Confucian interpretation of life". As a result, hierarchical principle of Confucianism is partly reflected in Vietnamese culture, which could be linked to high Power Distance cultural value.

Reflecting on the aforementioned findings in relation to the analytical framework, House's model (2015), extended with Appraisal theory (Martin \& White, 2005) has been proved to be 
useful in assessing the translation of person reference forms from English to Vietnamese. The factors affecting the way interlocutors address each other include social status, social role relationship, and the social attitudes of the interlocutors in specific communicative situations, which are fully discussed in House's model (2015). More importantly, this model embraces both context of situation and context of culture in assessing translation of person reference forms from English to Vietnamese. I assume that language can merely be fully understood when these situational and cultural contexts are fully understood by the interlocutors. As an example, depending on the "context of situation" and "context of culture" in Vietnam, a person named Nguyễn Thị A might be addressed as "bà, bác, cô, chị, em, mình, đằng ấy, ả, mụ” and so forth. The options of being called as "bà, bác, cô, chị, em, mình, đằng ấy, ả, mụ” also closely relate to the specific social role relationship such as the relationship at family or at work or with family, the social status, the social attitude, and the level of intimacy.

Throughout this study, Appraisal theory has been shown to be of practicality in describing the author's attitude embedded in the chosen literary text. Appraisal theory sheds light on how the author expresses his/ her subjective attitude via language. Attitude domain in Appraisal theory is concerned with our feelings, including emotional reactions, judgments of behavior and evaluation of things. For these reasons, House's model, extended with Attitudinal resources in Appraisal theory (Martin \& White, 2005) proves its applicability in assessing the translation of person reference forms from English to Vietnamese.

\section{Concluding remarks}

The use of person reference forms in literary texts is particularly intriguing. In literary texts, they are employed flexibly and plentifully with literary talent to depict the characters' personalities and intricate relationships between the characters and their attitudes towards each other. They are also used to disclose the author's attitudes and feelings towards his/ her characters. The meanings conveyed by the author through his/ her use of person reference forms contribute significantly to the overall effect of the literary text.

Theoretically, the study has shown the usefulness of supplementing House's model (2015) with Attitudinal resources of Appraisal theory in order to uncover the author's attitudes embedded in the original. This supplementation is reasonable because Appraisal theory is for exploring, describing, explaining the way language is used to evaluate, adopt stance, to construct interpersonal positionings and relationships (White \& Eldon, 2012). The selection of equivalents among Vietnamese system of person reference forms depends on a number of contextual factors, including social status, social role relationship, and social attitude in specific communicative situations. These parameters are fully discussed in House's model (2015) as well as Attitudinal resources of Appraisal theory (Martin \& White, 2005).

Practically, the use of target languageoriented translation strategy is recommended in dealing with person reference forms from English to Vietnamese. This strategy has lead to the gain of socio-cultural and pragmatic implications of Vietnamese forms of person reference. Via this strategy, the translator 
breaks through the cultural barriers between English and Vietnamese in order to recreate a functional translation in Vietnamese context.

\section{References}

\section{Vietnamese}

Diệp Quang Ban (2003). Giao tiếp, văn bản, mạch lạc, liên kết, đoạn văn. Hà Nội: NXB Khoa học xã hội.

Diệp Quang Ban, Hoàng Văn Thung (1996). Ngr̃ pháp tiếng Việt. Hà Nội: NXB Giáo dục.

Nguyễn Thiện Giáp (2004). Dụng học Việt ngũ. Hà Nội: NXB ĐHQGHN.

Cao Xuân Hạo (2001). Tiếng Việt, văn Việt, nguoòi Việt. Hà Nội: NXB Trẻ.

Nguyễn Hoà (2018). Giá trị văn hoá: Một số hàm ý cho nghiên cứu ngôn ngữ trên cơ sở giá trị văn hoá và giao tiếp liên văn hoá. Nghiên cứu Nước ngoài, 34(1), p. 1-15.

Hofstede, G. (2010). Translated by Đinh Việt Hoà (2015). Văn hoá và tổ chức: Phần mềm tu duy. Hà Nội: NXB ĐHQGHN.

Nguyễn Quang (2018). Chủ quan tính và khách quan tính trong hệ thống xưng hô Việt và Anh. Nghiên cưu Nước ngoài, 34(1), 16-34.

Trần Ngọc Thêm (1999). Co sở văn hoá Việt Nam. Hà Nội: NXB Giáo dục.

\section{English}

Braun, F. (1988). Terms of Address: Problems of Patterns and Usage in Various Languages and Cultures. Berlin: Mouton de Gruyter.

Brown, R. \& Gilman, A. (1960). The Pronouns of Power and Solidarity. In Sebeok, T. A. (ed.), Style in Language, 253-276. Cambridge, Mass: MIT Press.

Davis, E.E. (2003). A Goblin or A Dirty Nose? The Translator: Studies in Intercultural Communication, 9(1), 65-100.
Goodman, J. E. (2005). Uniquely Vietnamese. Hanoi: The Gioi Publisher.

Halliday, M. A. K. (1973). Explorations in the Functions of Language. London: Arnold.

House, J. (1977). A Model for Translation Quality Assessment. Tübingen: Gunter Narr Verlag.

House, J. (1997). Translation Quality Assessment: A Model Revisited. Tübingen: Gunter Narr.

House, J. (2015). Translation Quality Assessment. Past and Present. New York: Routledge.

Luong, H. V. (1990). Discursive Practices and Linguistic Meanings: The Vietnamese System of Person Reference. Amsterdam and Philadelphia: John Benjamin.

Martin, J. R. (2000). Beyond Exchange: Appraisal Systems in English. In Hunston, S. \& Thompson, G. (eds.), Evaluation in Text. Oxford: Oxford University Press.

Martin, J. R. \& White, P. R. R. (2005). The Language of Evaluation: Appraisal in English. Hampshire \& New York: Palgrave Macmillan.

Nguyễn Văn Huyên (2002). The ancient civilization of Vietnam. Hanoi: The Gioi Publisher.

Quirk, R. (1973). A Grammar of Contemporary English. England: Longman Group.

Rowling, J. K. (1997, 2014). Harry Potter and the Philosopher's Stone. London: Bloomsbury.

Steiner, E. (1998). A Register-based Translation Evaluation: An Advertisement as a Case in Point. Target 10(2), 291-318.

Triệu Thu Hằng (2018). Translating Proper Names in a Literary Text: A Case of Harry Potter Novel in Vietnam. Nghiên cứu Nước ngoài, 34(2), 39-50.

White, P. \& Eldon, (2012). The Language of Attitude, Arguability and Interpersonal Positioning. Retrieved 24 $4^{\text {th }}$ July from http:// www.grammatics.com

Yule, G. (2006). The Study of Language. UK: Cambridge University Press. 


\title{
ĐÁNH GIÁ DỊCH ANH-VIỆT CÁC BIỂU THỨC QUY CHIẾU VỀ NGƯỜI TRONG VĂN HỌC: HÂNH TRİNH CHUYỂN NGŨ "HARRY POTTER" TỪ ANH SANG VIẸT
}

\author{
Triệu Thu Hằng \\ Trưòng Đại hoc Ngoại ngũ - ĐHQGHN, \\ Phạm Văn Đồng, Cầu Giấy, Hà Nội, Việt Nam
}

Tóm tắt: Nghiên cứu này đánh giá dịch Anh-Việt các biểu thức quy chiếu về người, đặc biệt là cặp từ "I - you" trong văn bản văn học. Thực hiện nghiên cứu, mô hình chức năng-dụng học của House (House, 2015), mở rộng với các nguồn ngôn ngữ thể hiện Thái độ theo thuyết Đánh giá ngôn ngữ của Martin \& White (2005), được lựa chọn làm khung phân tích cho quá trình đánh giá. Dữ liệu bao gồm 75 cặp từ "I you" thu thập từ bản gốc "Harry Potter and the Philosopher's Stone" (2014) và bản dịch tiếng Việt "Harry Potter và Hòn đá phù thuỷ” (2016). Kết quả nghiên cứu cho thấy nỗ lực của người dịch trong việc lựa chọn tương đương trong một hệ thống quy chiếu về người vô cùng đa dạng của tiếng Việt để đem đến một bản dịch phù hợp với ngôn cảnh tình huống cũng như ngôn cảnh văn hoá của ngôn ngữ đích. Dựa trên kết quả nghiên cứu, chúng tôi đề xuất chiến lược dịch hướng đích đối với dịch các biểu thức quy chiếu về người trong văn học. Ngoài ra, nghiên cứu khẳng định hiệu quả của việc mở rộng mô hình của House với các nguồn ngôn ngữ thể hiện Thái độ theo thuyết Đánh giá ngôn ngữ (Martin \& White, 2005) để khám phá thái độ của tác giả ẩn trong văn bản nguồn, phục vụ thực tiễn đánh giá.

Tù̀ khoá: các biểu thức quy chiếu về người, đánh giá chất lượng bản dịch, dịch văn học 